\title{
Economics of ecological and biological development and labor market of agro-industrial complex
}

\author{
Vladimir Smirnov ${ }^{1,2}$, Marina Danilina ${ }^{1,2,3}$, Irina Omelchenko ${ }^{2}$, and Ludmila Botasheva ${ }^{1}$ \\ ${ }^{1}$ Financial University under the Government of the Russian Federation, Moscow, Russia \\ ${ }^{2}$ Russian Research Institute (VNII) of Labor, Moscow, Russia \\ ${ }^{3}$ Plekhanov Russian University of Economics (PRUE), Moscow, Russia
}

\begin{abstract}
The agro-industrial complex faces lots of challenges which brake its efficient economic, ecological and biological development and labor market functioning. Applying statistical analysis of the current indicators we estimate the influence of the negative factors and propose the possible solution. Despite its huge potential, the Russian agro-industrial complex is currently in a state of deep systemic crisis. The development of the agro-industrial complex is directly related to the quality of life of the rural population and the situation in the labor market. The possible solution is to develop engineering, social and transport infrastructure and improve the situation in the labor market in the rural areas. It is the state regulation and support of the agro-industrial complex that is currently the fundamental point of solving existing problems. To maintain efficiency in the agricultural sector, state regulation and support are not just necessary, but unavoidable. For effective operation and systematic development of the agro-industrial complex, it is necessary to form a program of state support for the sector in order to attract investment and innovation.
\end{abstract}

\section{Introduction}

Environmental and biological development in Russia is linked to the agro-industrial complex (AIC). The Russian economy is distinguished by a high degree of resource intensity. Natural resources, our country is rich, are used with low efficiency. Meanwhile, it is important to understand that economic, ecological and biological development are closely related.

This, in turn, is associated with the development of the labor market. A new trend in the modern labor market is the development of a policy to promote employment of the population based on the principles of a green economy. A distinctive feature of such a policy is the formation of an environmentally oriented labor market through the creation of green jobs that help reduce the negative impact on the environment and improve the environmental situation.

One of the first scientists who drew attention to the strengthening of the relationship between work, jobs and possible destruction of the environment was the Swiss economist HK Binswanger, who explored the boundaries of the welfare state in his work "Working without destroying the environment. New Economic Policy Strategies" [1]. 
However, the object of his main attention was the issues of possible loss of jobs, which was caused by environmental pollution and destruction of nature as the basis of the economy, including in connection with the filing of claims against environmentally unfavorable enterprises, up to their closure, re-profiling for environmental reasons [2]. We can say that the formation of scientific views and ideas about green employment dates back to the mid-90s of the XX century [3].

The analysis shows that the implementation of policies in the management of green employment has its own characteristics in the context of certain types of economic activity, which should be taken into account when developing and implementing national strategies for socio-economic development.

Along with a qualitative analysis of the relationship between aggravating environmental and climatic problems and the labor market, appropriate quantitative assessments of changes in the labor market in the context of new global challenges are also needed. It is about assessing the impact of environmental changes on labor market indicators.

At the same time, the environmental impact of the rapidly changing labor market must be considered.

\section{Materials and Methods}

The current research uses statistical data and methods in order to analyze the situation in agro-industrial complex in the sphere of ecological and biological development and labor market and find the problems of the recent years on the basis of the main indicators. Among these indicators were chosen the current (operating) costs of environmental protection, the average nominal accrued wage of fully workers in the organizations by economic activities, referred to the agro-industrial complex.

At the moment, the current (operating) costs of environmental protection are not at the proper level. This creates problems for the ecological and biological development of the country and, in particular, the agro-industrial complex. The detailed analysis of the current (operating) costs of environmental protection in the Russian Federation on 24.04.2020 (table 1) shows that amount of costs constantly grew in almost all types of costs except for research and development activities to reduce negative anthropogenic impacts on the environment where the amount of costs started to diminish from 2013. The total amount of current (operating) costs of environmental protection in 2019 reached 374411 million rubles.

The analysis of the average nominal accrued wage of fully workers from December 2019 till June 2020 showed the decline of this indicator in the sphere of the agro-industrial complex in the beginning of the third quarter of this year. It showed that many enterprises of the agro-industrial complex did not cope with the current crisis and the spread and influence of the COVID-2019 pandemic. 
Table 1. Current (operating) costs of environmental protection in the Russian Federation on 24.04.2020 (at actual prices; million rubles).

\begin{tabular}{|c|c|c|c|c|c|c|c|c|c|c|}
\hline & & \multicolumn{9}{|c|}{ Including: } \\
\hline & 푱 & 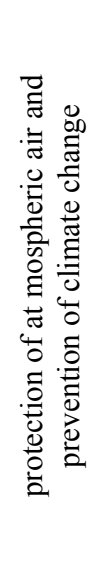 & 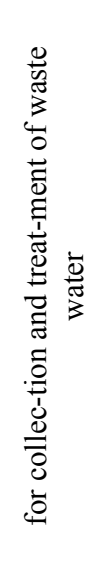 & 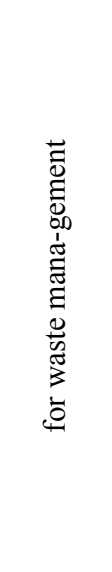 & 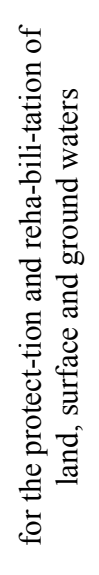 & 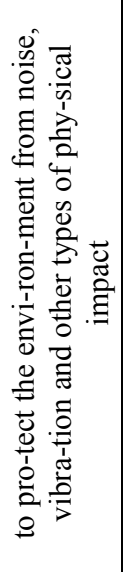 & 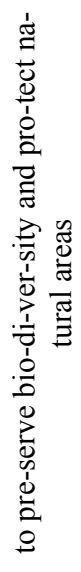 & 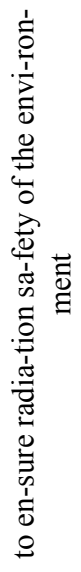 & 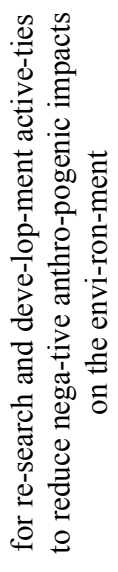 & 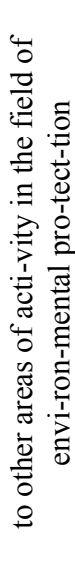 \\
\hline 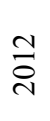 & 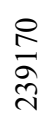 & 47062 & 121332 & 45798 & 13701 & 262 & 534 & 4795 & 460 & 5225 \\
\hline$\stackrel{m}{\stackrel{n}{\sim}}$ & 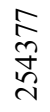 & 44800 & 132818 & 50402 & 15337 & 273 & 314 & 5342 & 1022 & 4069 \\
\hline$\underset{\sim}{\stackrel{\Delta}{\Delta}}$ & $\begin{array}{l}\infty \\
\text { N } \\
\infty \\
\stackrel{d}{0}\end{array}$ & 50920 & 136468 & 55702 & 15266 & 308 & 350 & 6088 & 937 & 3799 \\
\hline$\frac{n}{\stackrel{n}{d}}$ & 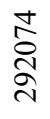 & 58250 & 145147 & 60256 & 16660 & 289 & 336 & 5459 & 582 & 5096 \\
\hline$\stackrel{0}{\stackrel{\sigma}{\sigma}}$ & 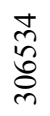 & 56851 & 154313 & 63580 & 19526 & 357 & 396 & 5843 & 647 & 5022 \\
\hline$\stackrel{\bar{c}}{\vec{i}}$ & $\begin{array}{l}\text { f } \\
\text { ᄋे } \\
\text { లn }\end{array}$ & 56906 & 163261 & 70041 & 15452 & 289 & 422 & 6328 & 464 & 7783 \\
\hline$\stackrel{\infty}{\stackrel{\infty}{\sim}}$ & $\begin{array}{l}\text { ț } \\
\text { 亗 } \\
\text { ఫे }\end{array}$ & 61075 & 173688 & 79885 & 15347 & 381 & 514 & 7728 & 205 & 6641 \\
\hline 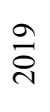 & 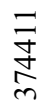 & 63760 & 174921 & 102396 & 16348 & 354 & 639 & 8266 & 219 & 7506 \\
\hline
\end{tabular}

Source: [4] Rosstat. 
Table 2. Average nominal accrued wage of fully workers in the organizations by economic activities (in accordance with OKVED2) in the Russian Federation in 2019-2020, rubles.

\begin{tabular}{|c|c|c|c|c|c|c|c|c|}
\hline & Dec. 19 & Jan.20 & Feb.20 & Mar.20 & Apr.20 & May.20 & Jun.20 & $\begin{array}{c}\text { June / } \\
\text { December } \\
\text { difference }\end{array}$ \\
\hline Total & 62239 & 46674 & 47257 & 50948 & 49306 & 50747 & 52123 & -10116 \\
\hline $\begin{array}{l}\text { agriculture, } \\
\text { forestry, } \\
\text { hunting, } \\
\text { fishing and fish } \\
\text { farming }\end{array}$ & 36986 & 30959 & 29561 & 32123 & 32458 & 34779 & 33871 & -3115 \\
\hline \multicolumn{9}{|l|}{ including: } \\
\hline $\begin{array}{l}\text { crop and } \\
\text { livestock } \\
\text { production, } \\
\text { hunting and } \\
\text { related services } \\
\text { in these areas }\end{array}$ & 32549 & 27469 & 26445 & 28806 & 29093 & 30473 & 30742 & -1808 \\
\hline $\begin{array}{l}\text { forestry and } \\
\text { logging }\end{array}$ & 43260 & 36941 & 36214 & 37286 & 36589 & 33930 & 35372 & -7888 \\
\hline $\begin{array}{l}\text { fishing and fish } \\
\text { farming }\end{array}$ & 107936 & 84428 & 73780 & 83457 & 87147 & 121797 & 90115 & -17821 \\
\hline $\begin{array}{l}\text { manufacturing } \\
\text { industries }\end{array}$ & 50745 & 43967 & 43510 & 46531 & 44596 & 44320 & 45925 & -4820 \\
\hline \multicolumn{9}{|l|}{ including: } \\
\hline food production & 37893 & 36138 & 34343 & 37976 & 36006 & 36501 & 36427 & -1466 \\
\hline $\begin{array}{l}\text { wood } \\
\text { processing and } \\
\text { manufacture of } \\
\text { wood and cork } \\
\text { products, } \\
\text { excluding } \\
\text { furniture, } \\
\text { manufacture of } \\
\text { articles of straw } \\
\text { and plaiting } \\
\text { materials }\end{array}$ & 30968 & 28710 & 28893 & 30774 & 28694 & 28980 & 30158 & -810 \\
\hline $\begin{array}{l}\text { production of } \\
\text { chemicals and } \\
\text { chemical } \\
\text { products }\end{array}$ & 63709 & 54148 & 52694 & 58651 & 60239 & 57115 & 56213 & -7497 \\
\hline $\begin{array}{l}\text { transportation } \\
\text { and storage }\end{array}$ & 58657 & 51822 & 49643 & 51784 & 54836 & 54024 & 52395 & -6261 \\
\hline $\begin{array}{l}\text { information } \\
\text { and } \\
\text { communication } \\
\text { activities }\end{array}$ & 93583 & 76215 & 78949 & 87942 & 92422 & 81754 & 82354 & -11230 \\
\hline
\end{tabular}

Source: [4] Rosstat.

As you know, the agro-industrial complex includes the following four components:

- Agriculture is the core of the agro-industrial complex, which includes crops, livestock, farms, personal subsidiary plots, etc. 
- $\quad$ Branches and services that provide agriculture with means of production and material resources: tractor and agricultural machine building, production of mineral fertilizers, chemicals, etc.

- Industries that are engaged in the processing of agricultural raw materials: food industry, industries for the primary processing of raw materials for light industry.

- Infrastructure block - production that deals with the procurement of agricultural raw materials, transportation, storage, trade in consumer goods, training for agriculture, construction in the agro-industrial complex.

At the same time, the following industries interact:

- $\quad$ Biochemistry (fertilizer production);

- $\quad$ Chemical industry;

- Timber industry (production of sawn timber for buildings, production of animal feed, production of fertilizers);

- Transport industry;

- $\quad$ Information Technology;

- $\quad$ Light industry.

There is no exaggeration to recognize that agriculture is the main activity in the country, because it is in APK includes industries that are responsible for the total food production. The country's supply of food, animal feed and raw materials depends on the efficiency of the agro-industrial complex.

Unfortunately, for many years, the Russian agro-industrial complex has been plagued by constant problems that hinder its effective operation and systematic development.

The development of agro-industrial and fishery complexes fraught with risks and threats that can significantly reduce the production potential, namely [5]:

1) economic risks due to the possibility of deteriorating internal and external economic environment, the slowdown in the global and domestic economy, high inflation and a banking crisis, decline in investment attractiveness of domestic agriculture and fisheries, reducing the competitiveness of domestic products;

2) technological risks caused by lagging in the level of technological development of the production base;

3) climate and agroecological threats caused by adverse climate changes and abnormal natural phenomena of a natural nature, an increase in the share of degraded land, a decrease in the fertility of agricultural land, the consequences of natural and man-made emergencies;

4) foreign policy risks that may limit the development potential of domestic agriculture and fisheries, caused by fluctuations in market conditions, and the use of state support measures for agriculture by foreign countries that distort international trade;

5) veterinary and phytosanitary risks associated with the emergence and spread of previously unregistered mass infectious animal diseases, as well as the spread of pests and plant diseases.

These risks provoke the following problems:

First of all, this is a weak supply of agricultural machinery and the processing industry of the agro-industrial complex. It should be taken into account that most enterprises still operate obsolete agricultural machinery and equipment, and the degree of wear and tear is often more than $50 \%$.

The dynamics of the power supply and power equipment in the Russian Federation show the slight fluctuation (table 3 ). 
Table 3. Power supply and power equipment in the Russian Federation, horsepower.

\begin{tabular}{|l|c|c|c|c|c|c|}
\hline & 2014 & 2015 & 2016 & 2017 & 2018 & 2019 \\
\hline Power supply & 201 & 197 & 200 & 198 & 200 & 199 \\
\hline Power equipment & 75 & 74 & 77 & 75 & 80 & 83 \\
\hline
\end{tabular}

Source: [4] Rosstat.

Secondly, the long-term practice of reducing production volumes, which is typical for the last decades, is a huge problem for the Russian agro-industrial complex. As a result, the area under cultivation and the number of livestock in animal husbandry were reduced to a minimum. This was a direct consequence of the state's activities-increased inflation, disruption of economic ties, reduction of state co-financing and provision of soft loans, and a decrease in the purchasing power of the population. Today, the infrastructure of the land market is stagnant, and huge potentially fertile areas of land are idle. Every year, thousands of hectares of land are withdrawn from agricultural circulation, and work on drainage, irrigation and land reclamation is almost suspended.

Third, information support and economic infrastructure in the agribusiness sector are developing very slowly, with a generally low level of financial education in the sector. As a result, the agribusiness sector is characterized by seasonal cash flows and a lack of its own current assets with high payables (the lion's share of which is fines and penalties for late payments). The banking sector and the tax system do not take into account the seasonal nature of production, which creates additional difficulties for farmers.

Together, these problems lead to a very low level of crop productivity in Russia (table 4). The analysis of the dynamic of the yield of the cereals and legumes showed the diminishment of the productivity in almost all groups of this type of crops.

Table 4. Crop yields (cereals and legumes) in the Russian Federation in agricultural organizations; hundredweight per hectare of harvested area.

\begin{tabular}{|l|c|c|c|c|c|}
\hline & 2014 & 2015 & 2016 & 2017 & 2018 \\
\hline Cereals and legumes & 25.4 & 25.0 & 27.6 & 31.0 & 27.2 \\
\hline wheat & 26.6 & 25.2 & 28.4 & 33.2 & 29.1 \\
\hline rye & 17.5 & 17.2 & 20.3 & 21.5 & 20.7 \\
\hline barley & 24.3 & 22.5 & 23.2 & 27.9 & 23.3 \\
\hline oats & 17.6 & 16.6 & 17.8 & 20.3 & 17.9 \\
\hline corn for grain & 43.9 & 51.4 & 57.5 & 50.0 & 51.6 \\
\hline millet & 12.7 & 13.6 & 15.5 & 12.1 & 11.8 \\
\hline buckwheat & 9.5 & 10.0 & 10.8 & 10.3 & 9.7 \\
\hline Rice & 54.2 & 56.5 & 53.8 & 54.3 & 59.2 \\
\hline leguminous crops & 15.3 & 16.7 & 18.1 & 21.0 & 13.8 \\
\hline
\end{tabular}

Source: [4] Rosstat.

The analysis of the dynamic of the yield of the industrial crops showed the diminishment of the productivity in almost all groups of this type of crops except for the sugar beet and the oilseeds (sunflower) (table 5).

The analysis of the dynamic of the yield of the fodder crops showed the diminishment of the productivity in almost all groups of this type of crops except for the forage root crops (table 6).

The analysis of the dynamic of the yield of the potatoes and the open ground vegetables showed the diminishment of the productivity of the potatoes and the slight increase of the productivity of the open ground vegetables (table 7). 
Table 5. Crop yields (industrial crops) in the Russian Federation in agricultural organizations; hundredweight per hectare of harvested area.

\begin{tabular}{|l|c|c|c|c|c|}
\hline & 2014 & 2015 & 2016 & 2017 & 2018 \\
\hline Industrial crops & 9.0 & 9.3 & 9.3 & 9.1 & 8.6 \\
\hline flax-dolgunets (fiber) & 3.9 & 4.8 & 5.0 & 6.5 & 3.1 \\
\hline Central Russian hemp fiber & 371.0 & 39.0 & 472.0 & 443.0 & 382.0 \\
\hline sugar beet & 12.9 & 13.6 & 14.6 & 14.6 & 15.1 \\
\hline Oilseeds & 14.0 & 15.2 & 16.0 & 15.1 & 16.7 \\
\hline sunflower & 12.4 & 13.6 & 16.0 & 14.7 & 15.6 \\
\hline soy & 5.9 & 5.1 & 5.5 & 7.0 & 4.6 \\
\hline mustard & 17.4 & 19.8 & 18.5 & 22.9 & 19.9 \\
\hline winter rapeseed & 11.4 & 10.0 & 10.2 & 14.4 & 12.3 \\
\hline spring rapeseed & 15.3 & 16.7 & 18.1 & 21.0 & 13.8 \\
\hline
\end{tabular}

Source: [4] Rosstat.

Table 6. Crop yields (fodder crops) in the Russian Federation in agricultural organizations; hundredweight per hectare of harvested area.

\begin{tabular}{|l|c|c|c|c|c|}
\hline & 2014 & 2015 & 2016 & 2017 & 2018 \\
\hline $\begin{array}{l}\text { forage root crops (including sugar } \\
\text { beet for livestock feed) }\end{array}$ & 209.0 & 210.0 & 215.0 & 179.0 & 183.0 \\
\hline annual grasses for hay & 16.3 & 16.1 & 19.6 & 18.3 & 17.0 \\
\hline annual herbs for green food & 71.0 & 73.0 & 77.0 & 85.0 & 76.0 \\
\hline $\begin{array}{l}\text { perennial grasses sown in the past } \\
\text { years for hay }\end{array}$ & 16.1 & 16.6 & 18.1 & 18.0 & 17.1 \\
\hline $\begin{array}{l}\text { perennial grasses sown in the past } \\
\text { years for green food }\end{array}$ & 102.0 & 107.0 & 111.0 & 112.0 & 104.0 \\
\hline
\end{tabular}

Source: [4] Rosstat.

Table 7. Crop yields (potatoes and the open ground vegetables) in the Russian Federation in agricultural organizations; hundredweight per hectare of harvested area.

\begin{tabular}{|l|c|c|c|c|c|}
\hline & 2014 & 2015 & 2016 & 2017 & 2018 \\
\hline potatoes & 207 & 234 & 226 & 258 & 256 \\
\hline open ground vegetables & 231 & 254 & 262 & 286 & 292 \\
\hline
\end{tabular}

Source: [4] Rosstat.

Fourth, the agrobusiness sector is completely unprotected from other industries. The problems of finding a market and the aggressive policy of intermediaries led to a multiple decrease in the share of agricultural producers in the retail price of the finished product. At the same time, it should be noted that the problem of sales for a domestic manufacturer is significantly complicated by high competition from foreign manufacturers, which in addition to production are ahead of domestic companies in terms of marketing and sales technologies. The situation is aggravated by the underdevelopment of agricultural markets and artificial regulation of product prices.

Fifth, the key problem of the agro-industrial complex was and still is the weak social development of villages and villages, which are the main motivators for the development of agriculture. The standard of living in villages and villages is still significantly inferior to the urban one, while having a negative impact on the economy of the agro-industrial complex. There are no opportunities to attract and train young professionals, which leads to the migration of residents and the extinction of entire settlements and villages. As a result, agriculture in the region is also dying, as it is the only source of income for the majority.

Sixth, the problem of agriculture is the heterogeneity of industries. In the agro-industrial complex, there is a relatively stable food industry aimed at the final consumer, and agriculture, which is in a difficult situation. 
The organization and working conditions in the agricultural sector are also not at the proper level. Let's analyze the main problems of the agro-industrial complex in details.

The difficult economic situation in the agro-industrial complex led to a sharp decrease in the level of effective employment of the rural population, led to the emergence of largescale stagnant unemployment and various forms of precarious low-income employment (work in private household plots, secondary, part-time, informal employment, etc.), as a reaction to negative macroeconomic shocks and the way survival.

As a result, the rural labor market turned out to be deformed. The modern labor market in the countryside is characterized by an increase in unemployment, a decrease in the quality characteristics of the labor force, and a mismatch in the structure of training agroindustrial complex personnel with the requirements of the labor market. It is characterized by a contradictory situation: in the presence of unemployment among rural residents, there is an increase in the real shortage of workers in the main mass professions in agriculture. The current situation testifies to the absence of state policy on the agricultural labor market, the state's withdrawal from solving the most important problem.

The formation and development of the rural labor market depends on many factors and conditions that determine its specific features, on the one hand, and, on the other hand, at the same time aggravating the situation: The current uneven distribution of the productive forces of rural areas in combination with the localization of regional labor markets and relatively low labor mobility.

Disintegration processes in the rural labor market cause the persistence of unemployment in some regions, while in some regions there is an acute shortage of labor in agriculture. In the rural labor market, structural imbalances in labor demand and supply are increasing. One of the reasons is the discrepancy between the structure of vocational education and the promising needs of the rural labor market in terms of qualifications and professional structure.

At present, the structure of agricultural vocational education is sharply shifted in favor of higher education, while the demand for skilled workers is not sufficiently satisfied. In the future, these imbalances may increase. The low level of wages and the further weakening of the stimulating role of wages, the low quality of jobs in agriculture aggravate the imbalances in the labor market, as a result, in this area, the negative trend of the outflow of highly qualified human resources may continue.

The natural decline of the rural population is stable and long-term due to a decrease in the birth rate and high premature mortality of the working-age population, which can lead to an increase in the shortage of labor resources in the countryside. Compared with the urban unemployed living in the countryside, the share of citizens with a higher professional education is significantly lower, and the share of citizens with a primary vocational education and no secondary general education is higher. Unemployment remains a female problem and also affects young people to a greater extent.

A significant proportion of underemployment and ineffective use of the labor force, which is in a forced idle time, may further lead to an aggravation of the situation on the labor market and an increase in actual unemployment. Unresolved issues of inter-sectoral redistribution of labor from the agrarian sphere, problems of sustainable development of rural areas lead to serious regional deformations in the rural labor market, given the absence of a housing market and weak territorial mobility of the labor force.

Insufficient development of the scale of agricultural production and service industries in the countryside, unsatisfactory working and living conditions; the preservation of numerous types of manual seasonal work in agriculture determines a high need for seasonal labor, while, as you know, the unemployed living in rural areas do not express the desire to work temporarily due to low pay, difficult working conditions and temporary nature of work, etc. 


\section{Results}

The lack of forecasts of real labor requirements, with the introduction of innovative technologies, a low level of reproduction of the vocational and qualification structure of those employed in agriculture. Among the factors that increase tensions in the rural labor market, three have the greatest impact: the continuing bankruptcy of the agro-industrial complex and the change in their owners, which is often accompanied by the liquidation of jobs; decline in the quality of the workforce; an increase in the number of unemployed people with reduced motivation to work.

In order to improve the situation on the rural labor market, achieve and maintain general and structural parity between supply and demand, targeted measures are needed to further develop the labor market and promote employment, to improve the rural environment and increase the attractiveness of the village as a place of work and life. Their implementation at the macro and micro levels will significantly reduce the scale of rural unemployment, especially in labor surplus regions and increase the level of employment and income of rural residents.

\section{Discussion}

As we found out, that at the moment the economical, ecological and biological development of agro-industrial complex and the situation in its labour market face a lot of challenges. The Order of the Russian Federation from April 12, 2020 N 993-p "On approval of "The strategy for the development of agro-industrial and fisheries complexes of the Russian Federation for the period up to 2030"'”. This document indicates that "the State policy in the field of agriculture and fisheries to the greatest extent affects the achievement of national goals, their main priorities aimed at supporting fertility, labor and employment, social security of the rural population, supporting entrepreneurship in rural areas, increasing the supply of housing in rural areas and improve its quality, increase in the level of technological development and digitalization, increase of level and quality of investment in fixed capital, increase of competitiveness of agro-industrial and fishery complexes based on the processes of import substitution" [5].

At the same time, according to this document, "the development of the agro-industrial complex is directly related to the quality of life of the rural population. It is necessary to take into account the need to develop engineering, social and transport infrastructure in rural areas" [5].

We must agree with the Order of the Russian Federation from April 12, 2020 N 993-p "On approval of The strategy for the development of agro-industrial and fisheries complexes of the Russian Federation for the period up to 2030" that the breakthrough development is needed to ensure the implementation of complex measures aimed at effective involvement of agricultural lands and development of land reclamation complex of the Russian Federation and formation of a common digital database, allowing you to aggregate all necessary information about the condition of the sectors, sub-sectors and areas of these complexes and their condition [5].

The state policy in the agro-industrial complex takes into account in the medium term the improvement of the quality of life of the rural population through the implementation of measures to create new small and medium-sized businesses, improve housing conditions, and increase the availability of social infrastructure. An important role in the development of agro-industrial and fisheries complexes is played by creating a high-quality educational environment for training highly qualified personnel for agriculture, food industry, fishing and fish farming [5]. 


\section{Conclusions}

In order to resume, on the basis of the analysis of the current situation, main indicators and problems of the development of the agro-industrial complex and its labor market, we came to the following conclusion. In general, despite a number of positive aspects, the Russian agro-industrial complex is in a state of deep systemic crisis, to get out of which its own forces are not enough and support from the state is necessary. It is the state regulation and support of the agro-industrial complex that is currently the fundamental point of solving existing problems. To maintain efficiency in the agricultural sector, state regulation and support are not just necessary, but unavoidable.

For effective operation and systematic development of the agro-industrial complex, it is necessary to form a program of state support for the sector in order to attract investment and innovation. With a competent approach, all problems can be solved, but this will require a long time and a systematic solution of the entire set of problems. Today, when Russia faces a lot of challenges, is in the grip of European sanctions, faces economic crisis and the pandemic COVID-19, it is time to turn your attention to the agro-industrial comples and agricultural sector-a sector that can ensure the country's food security and become the main segment of the implementation of import substitution policy.

\section{References}

1. H.K. Binswanger Arbeit ohne Umweltzerstoerung. Strategien einer Wirtschaftspolitik. Frankfurt am Main, S.Fischer Verlag, 367 (1983)

2. I.M.Potravny Ekologicheskii audit: teoriia i praktika: uchebnik dlia studentov vuzov 583 (2013)

3. O. Mehmet Employment creation and green development strategy. Ecological Economics, 15, 1, 11-19 (1995)

4. Rosstat, official site, 2020, www.rosstat.gov.ru

5. The Order of the Russian Federation from April 12, 2020 N 993-p "On approval of The strategy for the development of agro-industrial and fisheries complexes of the Russian Federation for the period up to 2030".

6. V.V. Arsenov, P.I. Ivantsov Innovatsionnoe razvitie agropromyshlennogo kompleksa Akademiya upravleniya pri Prezidente Respubliki Belarus' (2018)

7. D.V. Zav'yalov Indikatory ustoichivogo razvitiya agropromyshlennogo kompleksa Sinergiya, 339 (2017)

8. T.V. Uskova. Agropromyshlennyi kompleks regiona: sostoyanie, tendentsii, perspektivy 534 (2018)

9. N.V. Novikova Arkhitektura predpriyatii agropromyshlennogo kompleksa , 280 (2017)

10. L. Pushkareva Economic Security Issues SSRN Electronic Journal (2019) doi:10.2139/ssrn.3505157 